\title{
Comparing tagging strategies: Effects of tags on retention rate, mortality rate and growth in hatchery-reared juvenile meagre, Argyrosomus regius (Pisces: Sciaenidae)
}

\author{
María del Mar Gil ${ }^{1,2}$, Miquel Palmer ${ }^{2}$, Amalia Grau ${ }^{1}$, Enrique Massutí ${ }^{1}$, Elena Pastor ${ }^{1}$ \\ ${ }^{1}$ Laboratori d'Investigacions Marines i Aqüicultura, LIMIA (Balearic Government). C/ Eng. Gabriel Roca 69, \\ 07157 Port d'Andratx, Balearic Islands, Spain. \\ (MMG) (Corresponding author) E-mail: mmgil@ dgpesca.caib.es. ORCID iD: http://orcid.org/0000-0002-1044-0312 \\ (AG) E-mail: amaliagrau @ dgpesca.caib.es. ORCID iD: http://orcid.org/0000-0002-6461-6985 \\ (EM) E-mail: emassuti@ dgpesca.caib.es. ORCID iD: http://orcid.org/0000-0001-6369-7077 \\ (EP) E-mail: epastor@ dgpesca.caib.es. ORCID iD: http://orcid.org/0000-0002-0130-2575 \\ ${ }^{2}$ Instituto Mediterráneo de Estudios Avanzados (IMEDEA), CSIC-UIB, Department of Ecology and Marine Resources, \\ Ichthyology Group. C/ Miquel Marquès 21, 07190 Esporles, Balearic Islands, Spain. \\ (MP) E-mail: palmer@imedea.uib-csic.es. ORCID iD: http://orcid.org/0000-0002-7875-3673
}

\begin{abstract}
Summary: The objective of this study was to compare the effectiveness of different tags (T-bar anchor tags, internal anchor tags and visible implant elastomers) implanted into juvenile meagre, Argyrosomus regius (Asso, 1801) for a restocking programme conducted in the Balearic Islands. Effectiveness was assessed in terms of tag loss, fish survival and fish growth by means of a tank experiment. The internal anchor tags showed the highest retention rate (100\%), but the tagging mortality was also high (40\%). The tagging mortality of T-bar tags was negligible. However, another tank experiment with different food rates showed the tag retention rate of the T-bar tag to be highly variable, ranging from $35 \%$ to $95 \%$. In contrast with other reported results, the retention rate of visible implant elastomers was low (48\%). Finally, none of the tested tags affected growth. In summary, the T-bar anchor tags showed the best trade-off between short-term tag retention and fish mortality, and seem to be the most suitable tagging method for meagre juveniles.
\end{abstract}

Keywords: anchor tags; Argyrosomus regius; growth; meagre; tag retention; tagging mortality; visible implant elastomer.

Comparación de diferentes estrategias de marcaje: Efectos en la tasa de retención, tasa de mortalidad y crecimiento de marcas alojadas en juveniles de corvina Argyrosomus regius (Pisces: Sciaenidae) criados en cautividad

Resumen: El objetivo de este estudio fue comparar la efectividad de diferentes marcas (marca con anclaje en T, marca con anclaje abdominal y marcaje con elastómero visible, VIE) implantadas en corvinas juveniles (Argyrosomus regius Asso, 1801) para un programa de repoblación llevado a cabo en las Islas Baleares. La efectividad fue evaluada en función de la pérdida de marcas, la supervivencia y el crecimiento de los peces mediante un experimento en tanque. Las marcas con anclaje abdominal presentaron la tasa de retención más alta (100\%), pero también presentaron la mayor tasa de mortalidad (40\%). La tasa de mortalidad de las marcas con anclaje en T fue despreciable. Sin embargo, otro experimento con diferentes tasas de alimentación mostró que la tasa de retención de las marcas T fue muy variable, oscilando entre un 35\% y un $95 \%$. En contraste con otros resultados publicados, la tasa de retención de los VIE fue baja (48\%). Finalmente, ninguna de las marcas testadas afectó al crecimiento. En resumen, las marcas con anclaje en T mostraron el mejor compromiso entre la tasa de retención a corto plazo y la tasa de mortalidad de los peces, y parece ser el método de marcaje más adecuado para los juveniles de corvina.

Palabras clave: marcas de anclaje; Argyrosomus regius; crecimiento; corvina; tasa de retención; mortalidad por marcaje; elastómero visible.

Citation/Como citar este artículo: Gil M.M., Palmer M., Grau A., Massutí E., Pastor E. 2017. Comparing tagging strategies: Effects of tags on retention rate, mortality rate and growth in hatchery-reared juvenile meagre, Argyrosomus regius (Pisces: Sciaenidae). Sci. Mar. 81(2): 171-178. doi: http://dx.doi.org/10.3989/scimar.04583.26B

Editor: E. Macpherson.

Received: November 22, 2016. Accepted: January 31, 2017. Published: April 18, 2017.

Copyright: () 2017 CSIC. This is an open-access article distributed under the terms of the Creative Commons Attribution (CC-by) Spain 3.0 License. 


\section{INTRODUCTION}

Mark-recapture methods are becoming widely available for modelling population dynamics and for assessing the success of management actions of fish stocks (Lorenzen 2005, Ye et al. 2005, Gil et al. 2015). In the case of restocking programmes aimed at enhancing stocks, the identification of released fish is essential. Reared individuals must be efficiently and unambiguously differentiated from wild stocks (Blankenship and Leber 1995, Chick 2010). Therefore, the development and testing of a reliable tagging method should precede any investment in restocking itself (Bell et al. 2006).

Tagging fish provides data invaluable not only for assessing a restocking programme but also for other objectives beyond restocking. These objectives include assessing the impact of escaped farm fish, studying fish movement patterns, and determining migration tendencies, growth rate, mortality rate and population abundance (Phelps and Rodriguez 2011, Arechavala-Lopez et al. 2017).

A great variety of tag types have been used to monitor stocked individuals, including electronic tags, biological tags, chemical tagging and physical tags (Leber and Blankenship 2011). Unfortunately, none of the current tagging methods guarantees complete effectiveness for any fish species. By contrast, they are highly species-specific, so the most appropriate tagging method should be specifically analysed for each species.

Meagre, Argyrosomus regius (Asso, 1801), is a large sciaenid whose populations have decreased steadily in Mediterranean waters (Quéro and Vayne 1987), and it is considered to be extinct in the Balearic Islands (western Mediterranean), where it was a relatively frequent capture only a few decades ago (Mayol et al. 2000). Therefore, the Balearic government qualified meagre as a suitable species for a restocking programme based on releasing hatchery-reared fish. Accordingly, more than 10000 juveniles tagged with T-bar anchor tags have been released since 2008. Although many studies of Argyrosomus regius have been conducted because of its commercial interest and because it has been shown to be a feasible candidate for the diversification of finfish marine aquaculture (Quéméner 2002, Jiménez et al. 2005), no study related to the effectiveness of tagging on meagre has been conducted to date.

Ideally, tagging should not influence the survival, growth or behaviour of the fish, and nor should tag loss occur. Nevertheless, tag loss occurs frequently, and the retention time typically depends on the type of tag. Tag loss may cause underestimation of survival rate for the hatchery-reared juveniles, and therefore an underestimation of restocking success. Results obtained from the meagre restocking programme conducted in the Balearic Islands showed that some tag loss occurred on the recaptured specimens several months after the release (Gil et al. 2014a). In the same study, the recaptured meagre juveniles showed that the released specimens experienced difficulty feeding during the first weeks after release into the wild (Gil et al. 2014a). Therefore, studies on tagging methodologies in meagre juveniles and the influence of the nutritional status on the tag retention appear to be necessary.

In this paper, a tank experiment to evaluate how the loss of T-bar anchor tags could be affected by feeding status was conducted using hatchery-reared juvenile meagre. The aim was to determine how this factor affected the tag retention rate in the meagre released during the restocking programme conducted in the Balearic Islands. In addition, the tag loss rate, survival rate and growth were compared for different tags (T-bar anchor tags, internal anchor tags and visible implant elastomers [VIE]) in a second tank experiment with juvenile meagre. Thereby, we evaluated which tagging method was the most effective and appropriate for meagre juveniles, to apply it in future releases of the restocking programme.

\section{MATERIALS AND METHODS}

This study was conducted at the LIMIA (Laboratori d'Investigacions Marines i Aqüicultura, Balearic Government) facilities in the Balearic Islands, Spain, using hatchery-reared juvenile meagre. The fish were spawned in May following the protocols developed by LIMIA (Pastor et al. 2013). The eggs were obtained by hormonal induction of meagre breeders captured in Cádiz Bay. During the hatchery phase, larvae were reared under controlled conditions and fed a diet comprising rotifers (day 2-15) and Artemia sp. (day 8-30). The fish fry, and later the juveniles, were fed commercial feed (Skretting ${ }^{\circledR}$, Burgos, Spain; day $>30$ ), first in tanks and later in small sea cages until they were used in the tank experiments.

\section{Tank experiments}

The tank experiments and fish tagging were approved by the ethics committee of LIMIA, which is a laboratory authorized for animal research (official register reference code ES070050000502). These tasks were conducted under veterinary supervision and minimized fish suffering, in accordance with the European Communities Council Directive 2010/63/EU, and in strict compliance with Spanish law (RD53/2013, BOE n. 34, 6 February 2013).

In the first experiment, a total of 60 five-month-old juveniles $\left(\mathrm{W}_{\mathrm{T}}=83.7 \pm 24.5 \mathrm{~g}\right.$ and $\left.\mathrm{L}_{\mathrm{T}}=19.5 \pm 1.9 \mathrm{~cm}\right)$ were tagged with T-bar anchor tags (Fig. 1A; Model FF-94; Floy Tag) and distributed in a 10000-L rectangular flat-bottom fibreglass tank divided into six sections (ten meagre per group). A flow-through open system allowed a renewal rate of $50 \mathrm{~L} \mathrm{~min}{ }^{-1}$, and the water temperature was maintained at $18.0 \pm 1.3^{\circ} \mathrm{C}$ through a heating system. The fish were subjected for 118 days to three different treatments: control, starvation and low diet, with two replicates for each treatment. The control fish were fed daily with fresh food (fish and squid) until satiation, and the starved fish were not fed throughout the experiment. The fish under a low diet were fed once a week with fresh food. Weekly, all fish were sampled $\left(\mathrm{W}_{\mathrm{T}}\right.$ and $\left.\mathrm{L}_{\mathrm{T}}\right)$, and the retention of the Tbar tags was checked. 

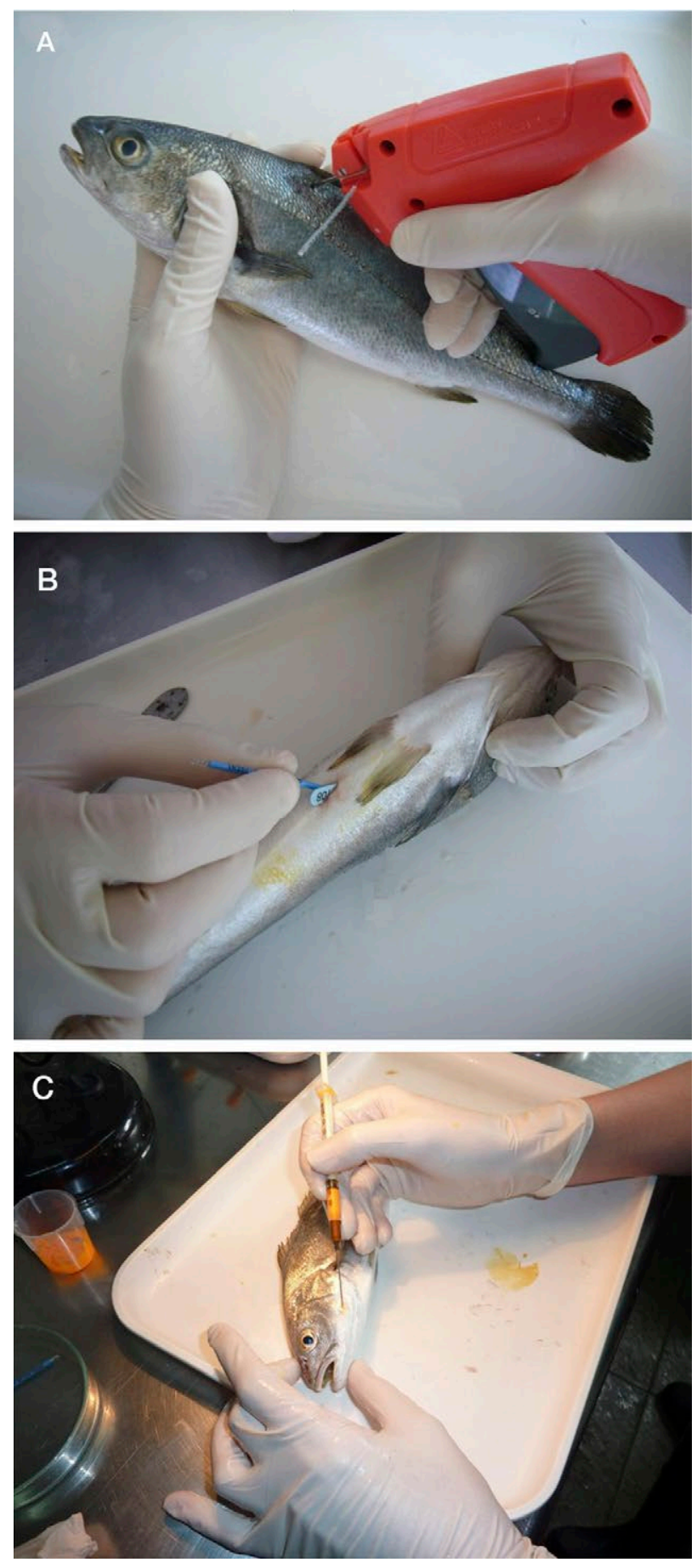

Fig. 1. - Tagging of A. regius juveniles with T-bar anchor tag (A), internal anchor tag (B), and VIE (visible implant elastomer) (C).

The second experiment was a double-tagging experiment. Double-tagging techniques can estimate tag loss rate of released fish (Wetherall 1982, Otterå et al. 1998) with the use of permanent tags, such as VIE (Hartman and Janney 2006) or coded wire tags (Henderson-Arzapalo et al. 1999), in order to distinguish individuals that have lost the tag from those that were never tagged. In this experiment, the tested putative permanent tag was the VIE. For 139 days, a total of 90 eight-month-old juveniles $\left(\mathrm{W}_{\mathrm{T}}=147.7 \pm 31.8\right.$ $\mathrm{g}$ and $\mathrm{L}_{\mathrm{T}}=24.4 \pm 1.6 \mathrm{~cm}$ ) were held in a $10000-\mathrm{L}$ tank divided into three sections (30 meagre per section). A flow-through open system allowed a renewal rate of 50 $\mathrm{L} \mathrm{min}^{-1}$, and the water temperature was $16.0 \pm 2.0^{\circ} \mathrm{C}$. Each section contained ten fish for each of the three tested treatments: (1) untagged control fish, (2) fish tagged with an orange VIE and T-bar anchor tag (Model FF-94; Floy Tag), and (3) fish tagged with a green VIE and internal anchor tag. At the beginning of the experiment, the control fish were sampled (recording $\mathrm{W}_{\mathrm{T}}$ and $\mathrm{L}_{\mathrm{T}}$ ) but not anaesthetized. The remaining fish were anaesthetized $\left(0.5 \mathrm{~mL} \mathrm{~L}^{-1} 2\right.$-phenoxyethanol) and sampled just prior to the tagging. The internal anchor tag (Fig. 1B; Model FM-95W; Floy Tag) was inserted into the abdominal cavity through an approximately 6-mm vertical incision made with a scalpel. The incision was allowed to close naturally (no suture stitches were applied). The VIE tags (Fig. 1C; NWMT, Shaw Island, WA) were inserted manually with a hypodermic syringe into the left inferior opercular area where the skin is thinner and whiter. Fish were fed daily with fresh food (until satiation). All fish were sampled twice a month, during which $\mathrm{W}_{\mathrm{T}}$ and $\mathrm{L}_{\mathrm{T}}$ data were taken, and the retention of the tags and healing of the internal anchor tags were checked. Fish mortality was recorded daily.

\section{Data analysis}

\section{Tag retention rate}

The first tank experiment provided data for estimating the effect of diet on the T-bar retention in meagre juveniles. The second experiment allowed for a comparison of tag retention rates between T-bar anchor tags, internal anchor tags and VIE in juveniles subjected to the same food conditions.

The differences in the tag retention time between treatments for each of these factors were analysed using the survival analysis method, which is designed to investigate the factors affecting the time at which a particular event (here, tag loss) occurs (Crawley 2007). Originally, the method was developed for medical survival analyses, but it has already been applied in other fields. To determine the differences in the tag retention rate between treatments, a proportional hazards model (or Cox regression model) was applied to the data. This model describes the probability per unit time of the event occurring as a function of a basic probability (the baseline hazard) and a set of explanatory variables (here, diet or tag type). Not all of the fish lost the tag within the duration of the experiment, so the partially missing data were considered as right-censored observations. The probabilistic nature of the model allowed the variation in the timing of the event (here, the percentage of tag retention) to be predicted. The coxph function from the survival library (developed by $\mathrm{T}$. Therneau and T. Lumleyat; http://cran.r-project.org/web/packages/survival/ survival.pdf) of the R package (at http://www.r-project. org/) was used to estimate the model parameters and likelihood ratios. The predicted survival rates at different times and treatments were estimated using the survfit function from the same library. 
Growth

The fish length $\left(\mathrm{L}_{\mathrm{T}}\right)$ dataset taken every 15 days during the second experiment was used to compare the effect of the T-bar and the internal anchor tags on the fish growth, using the untagged fish as a control.

The size-at-age data of each fish were fitted to a version of the Von Bertalanffy growth model, allowing for seasonal oscillations (Gil et al. 2014b):

$$
\mathrm{L}_{\mathrm{t}}=\mathrm{L}_{0}+\left(\mathrm{L}_{\infty}-\mathrm{L}_{0}\right)\left(1-\exp \left(-\mathrm{K}\left(\mathrm{t}-\mathrm{t}_{0}\right)-\mathrm{S}_{\mathrm{t}}+\mathrm{S}_{\mathrm{t} 0}\right)+\varepsilon_{\mathrm{t}}\right.
$$

where

$$
\begin{gathered}
\mathrm{S}_{\mathrm{t}}=(\mathrm{CK} / 2 \pi) \sin \left(2 \pi\left(\mathrm{t}-\mathrm{t}_{\mathrm{s}}\right)\right) \\
\mathrm{S}_{\mathrm{t} 0}=(\mathrm{CK} / 2 \pi) \sin \left(2 \pi\left(\mathrm{t}_{0}-\mathrm{t}_{\mathrm{s}}\right)\right) \\
\varepsilon_{\mathrm{t}}=\operatorname{Normal}\left(0, \mathrm{sd}_{\mathrm{Lt}_{\mathrm{t}}}\right)
\end{gathered}
$$

In this parameterization, $\mathrm{L}_{0}$ is the averaged total length of the fish at the beginning of the experiment $(24.5 \mathrm{~cm})$, and $t_{0}$ is the fish age at the beginning of the experiment (263 days). $\mathrm{L}_{\infty}$ was assumed to be $171.9 \mathrm{~cm}$ (González-Quirós et al. 2011); however, the value of this parameter did not affect the estimates of size-at-age. The remaining parameters $\mathrm{C}$ (which modulates the amplitude of the seasonal growth oscillations), $\mathrm{K}$ (the rate of approach to the asymptotic length) and $t_{S}$ (the time between $t_{0}$ and the inflection point of the first sinusoidal growth oscillation) were estimated using a Bayesian approach. Three chains were run using randomly selected initial values for each parameter within a reasonable interval, and conventional convergence criteria were checked. The number of iterations was selected for each run to obtain at least 1000 valid values after convergence and thinning. The models were implemented with the library R2jags (http://cran.r-project.org/web/packages/ R2jags/R2jags.pdf) of the R package, which uses the samplers implemented in JAGS (http://mcmc-jags. sourceforge.net/).

Growth differences were analysed by comparing the $\mathrm{K}$ values obtained for the fish tagged with the $\mathrm{T}$ bar tag, the fish tagged with an internal anchor tag and the control fish. The $\mathrm{K}$ parameter is a measure of the exponential rate of approach to the asymptotic length (Schnute and Fournier 1980). Therefore, for the same $\mathrm{L}_{\infty}, \mathrm{K}$ is representative of the growth rate.

\section{Mortality rate}

Fish mortality among different tagging methods was compared and analysed using death events recorded during the 139 days in the second experiment. Thus, the mortality of fish tagged with T-bar tags and internal tags and the untagged fish (control) were compared.

The differences in mortality between tagging methods were analysed using the same survival method as that detailed above. In this case, the model describes the probability per unit time of a death event occurring as a function of the explanatory variable, i.e., the type of tag.

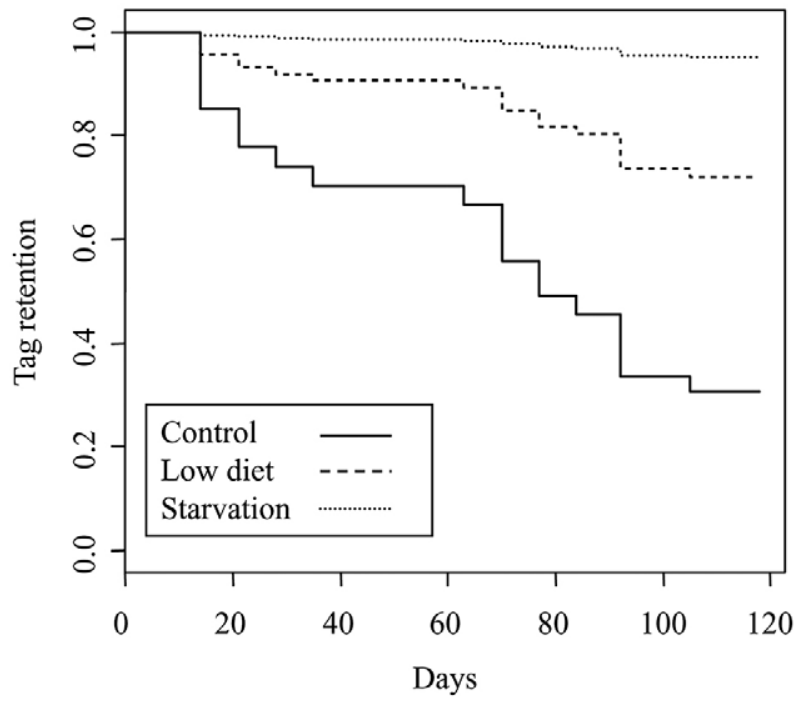

Fig. 2. - Estimated T-bar tag retention for the diet factor. Comparison between the three diet conditions tested: control, low diet and starved.

\section{RESULTS}

\section{Effect of diet on T-bar anchor tag retention}

The T-bar tag retention rate fitted using the Cox model was estimated for the different treatments of diet: control (fed every day), low diet (fed once a week) and starvation (unfed). The probabilities of tag retention over time were found to be significantly affected by the treatments (Coefficient $=20.48, \mathrm{df}=2, \mathrm{p}<0.05$ ). Therefore, the diet (i.e. amount of food given to the fish) significantly influenced the tag retention (Fig. 2 ). The fish subjected to a low diet showed higher tag retention $(70 \%)$ than the control fish fed daily $(35 \%)$. However, the starved fish showed the highest tag retention rate $(95 \%)$ because they retained almost all of the tags during the 118 days of the experiment.

\section{Comparison of different tags}

The tag retention observed with the T-bar anchor tag, internal anchor tag and elastomers in the second experiment was analysed separately (Fig. 3). The survival analysis showed that the tag retention for the $\mathrm{T}$ bar $(92.3 \%)$ was significantly higher than that for the elastomer, which retained just $48 \%$ of implanted tags (Coefficient $=16.09, \mathrm{df}=1, \mathrm{p}<0.05)$. The fish tagged with the internal anchor tag were not included in the analysis because no tag was lost during the course of the experiment (139 days). The survival analysis requires at least one event to occur during the study period.

The effect on growth on the fish tagged with the T-bar and internal anchor tag and the control fish (untagged) was studied using a Bayesian inference, which facilitates the estimation of individual growth parameters and between-fish variability. The $\mathrm{K}$ parameter (i.e. the exponential rate of approach to the asymptotic length) was similar for all the treatments (Fig. 4), indicating no effect on growth in fish tagged with different types of tags. 


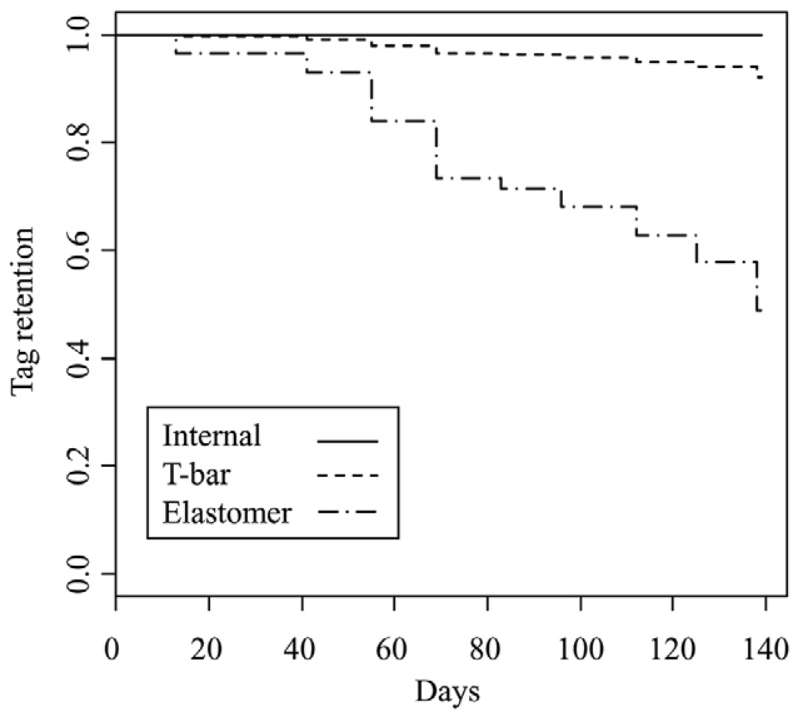

Fig. 3. - Estimated tag retention for the three different tags tested in the second experiment: internal anchor tag, T-bar anchor tag and elastomer.

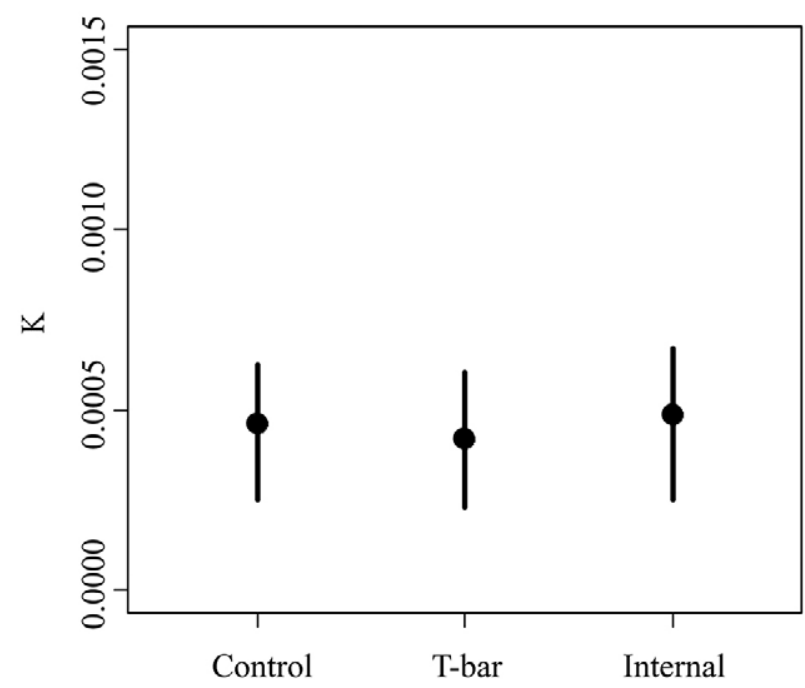

Fig. 4. - Values of the parameter K estimated for the von Bertalanffy growth model with seasonal oscillations for the control fish and the fish tagged with T-bar and internal anchor tags. The dots are the median values, and the vertical lines are the $2.5 \%$ and $97.5 \%$ percentiles.

The mortality recorded during the second experiment was analysed separately for the three treatments tested (Fig. 5): T-bar anchor tag, internal anchor tag and control fish (untagged). The fish tagged with the internal anchor tag showed the lowest survival rate $(60 \%)$, which was significantly lower than the mortality rate of the untagged (control) fish $(\mathrm{p}<0.05)$. Conversely, the fish tagged with the T-bar anchor tag showed a survival rate $(83.3 \%)$ very close to and not significantly different from that experienced by the control fish $(p=0.9)$.

\section{DISCUSSION}

Restocking is increasingly used for enhancing fish stocks, but the success of restocking programmes has rarely been assessed. Natural and fishing mortality of the released fish can be estimated from the temporal

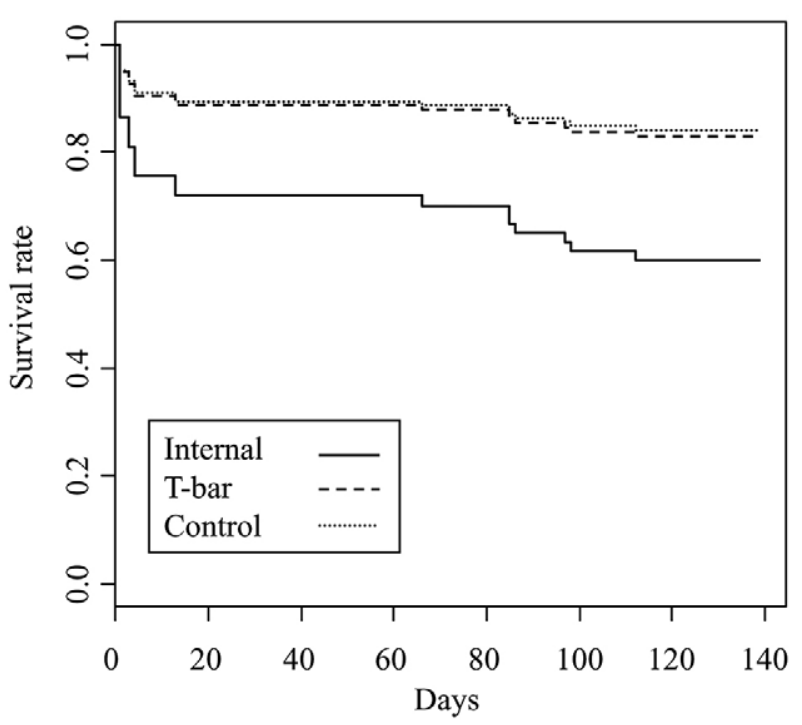

Fig. 5. - Estimated survival rate for the three treatments tested in the second experiment: internal anchor tag, T-bar anchor tag and control fish (untagged).

distribution of returned fish after a number of release events (Gil et al. 2015), but the precision of this or any other demographic parameter depends on the amount and temporal distribution of the fish reported by fishermen. In general, returned fish are essential for assessing the success of any restocking programme that measures the survival and growth of the released fish (Chick 2010). The optimal tag should cause no deleterious effect, and it should not be lost at any moment. Ignoring lost tags implies mortality overestimation, and it may induce the wrong conclusion on the success of a restocking programme. Therefore, this study compared several tagging techniques to select the best method for identifying the released meagre when they are recaptured from the wild by fishermen after an extended period.

The T-bar anchor tag has been widely used in several studies because it is quickly and easily applicable (Astorga et al. 2005), so this tag type was selected for the restocking programme with meagre juveniles conducted in the Balearic Islands. However, some tag losses were observed on the recaptured meagre several months after the release (Gil et al. 2014a). In this study, T-bar tags showed a high variability in retention time in juvenile meagre, as has been observed in other studies. For example, after 1 year, the T-bar anchor tag retention was $93 \%$ for Arctic grayling, Thymallus arcticus (Pallas) (Buzby and Deegan 1999), and 89\% for lake whitefish, Coregonus clupeaformis (Mitchill) (Ebener and Copes 1982). In contrast, the anchor tag retention was $42 \%$ after one year for striped bass, Morone saxatilis (Walbaum), (Waldman et al. 1991), 25\% after 560 days for white bass, Morone chrysops (Rafinesque) (Muoneke 1992), and 9\% after 198 days for red roman, Chrysoblephus laticeps (Valenciennes), (Kerwath et al. 2006). The high tag retention differences can vary between tagging methods, between tag size, between species and within species (Booth and Weyl 2008).

The diet comparison in this study showed a significantly lower T-bar tag retention rate for well-fed fish. 
The tag loss could be related to scraping against hard structures or the high fish densities (Sánchez-Lamadrid 2001, Booth and Weyl 2008). Therefore, an optimal nutritional condition may result in an increased activity pattern, thus favouring tag loss. Released meagres in the Balearic restocking programme need a relatively long time to adapt to wild food (Gil et al. 2014a). Shortterm tag loss seems to be smaller, and may be related to suboptimal diet of recently released fish, which may be less active than fully feed fish, as suggested by the tank experiment. However, the tag loss rate estimated from this experiment should be extrapolated to the wild with caution because the characteristics of the natural environment, fish behaviour in the wild and interspecies interactions could modify the results (Sato et al. 2016). Therefore, further tag retention studies should be conducted under natural conditions (Booth and Weyl 2008).

The tag retention studies that have been conducted under natural conditions have mainly used doubletagging approaches (Adam and Kirkwood 2001, Booth and Weyl 2008, Venerus et al. 2013). However, one constraint of these studies is the loss of both tags, so a "permanent tag" such as PIT, CWT or VIE has been used for comparison (Brennan et al. 2005, Josephson et al. 2008, Rude et al. 2011). In this study, the experiment conducted with the T-bar anchor tag, internal anchor tag and VIE had two goals: to seek an alternative to T-bar anchor tag (in the case of the internal anchor tag), and to select a "permanent tag" for future experiments under natural conditions (in the case of VIE). A very high retention rate was observed for the internal anchor tag (100\% after 139 days). Similarly, Wallin et al. (1997) reported a retention rate higher than $99 \%$ after 30 days for common snook, Centropomus undecimalis (Bloch), and Dunning et al. (1987) reported $98 \%$ after one year for striped bass. The insertion of the internal anchor tag is a process which is far more traumatic than the insertion of the $\mathrm{T}$-bar anchor tag because it requires a large incision in the abdominal wall and anaesthesia. This fact was reflected by the high mortality of meagre (40\%). However, in previous studies this high mortality was not

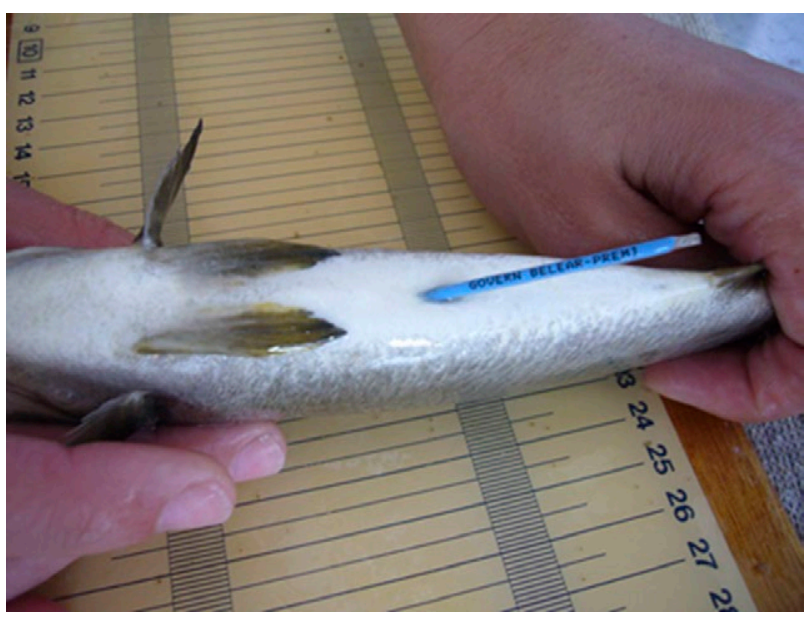

Fig. 6. - A. regius with internal anchor tag as seen 125 days post-tagging.
Table 1. - Pros and cons of the tested tagging methods for meagre juveniles. ${ }^{a}$ This method requires the fish to be anaesthetized (included in the marking time).

\begin{tabular}{lccc}
\hline & T-bar & Internal & VIE \\
\hline $\begin{array}{l}\text { Easily identified by the } \\
\text { fishermen }\end{array}$ & Yes & Yes & No \\
Identification of fish & Individual & Individual & Cohort or group \\
Cost & $0.67 € /$ tag & $1.021 € /$ tag & $0.14 € /$ tag \\
Marking time & 3 seconds & $2-3$ min $^{\mathrm{a}}$ & $2-3 \mathrm{~min}^{\mathrm{a}}$ \\
\hline
\end{tabular}

observed (Dunning et al. 1987, Wallin et al. 1997). Additionally, in some studies, irritation, haemorrhage and secondary infection around the insertion site have been reported (Vogelbein and Overstreet 1987, Phelps and Rodriguez 2011). However, successful healing and a lack of infection were observed in the fish tagged with internal anchor tags that survived in the tank experiment (Fig. 6). Conversely, the mortality observed with the T-bar anchor tags (16.7\%) was the same as that of the untagged fish, so this mortality could be attributed to the handling and tank conditions but not to the process of tagging with T-bar tags.

Contrary to expectations, VIE showed a low retention rate in this study (48\%), whereas high retention had been reported elsewhere (Catalano et al. 2001, Brennan et al. 2005, Kerwath et al. 2006). VIE tends to fragment over time and thus may became difficult to see (Astorga et al. 2005); however, this was not the problem in this study because VIE began to disappear several weeks after implantation. In the case of VIE, body location, the experience and ability of the personnel and the amount of elastomer injected can significantly influence tag retention and visibility. Nevertheless, the results reported here do not support the use of this method for meagre juveniles.

Finally, none of the tested tags interfered with the growth of meagre juveniles because no differences with untagged fish were observed. This result is in accordance with other tagging experiments conducted in other species with the same tag types (Otterå et al. 1998, Phelps and Rodriguez 2011). Similar growth rates indicate that the use of different tag types does not affect the behaviour of the fish or cause stress (Morgan and Walsh 1993).

In addition to retention rate, mortality and growth, other aspects can be analysed to determine the pros and cons of the T-bar tag, internal anchor tag and VIE (Table 1). VIEs have a low cost but are ineffective for tagging meagre. Internal anchor tags have a high retention and are visible by fishermen, but they showed a high mortality. Therefore, these two methods are clearly unsuitable for meagre. T-bar anchor tags have a quick and easy application and a low cost, allowing a large number of meagre to be tagged in a short time. Furthermore, they are visible by fishermen who may provide individual information of the recaptured meagre, allowing detailed studies about movement, growth, feeding or survival to be conducted. However, evidence both in the wild and in tank experiments suggests that the T-bar tags can show an important loss rate over time, which may introduce some biases if ignored or imply additional modelling complexities in the analysis of data obtained in this way. 
Therefore, to ensure sufficient data for the meagre restocking programme, other tagging methods should be evaluated in the future. Another option would be a double-tagging method combining a T-bar anchor tag and a "permanent tag". Previous studies have proven that alizarin red (ALR) immersion marking is a successful marker of meagre otoliths, and it produces a low mortality and remains over time (Morales-Nin et al. 2010). Therefore, ALR bath could be used as a "permanent tag" because, although the recaptured fish could not be individually identified, the analysis of the otolith would allow it to be assigned to a particular release event. Thus, meagres that have lost the external tag an extended period after being freed could be identified, providing important information for assessing the success of a restocking programme (Gil et al. 2015).

\section{ACKNOWLEDGEMENTS}

This work is a result of the IMEDEA (CSIC/UIB)LIMIA Associated Unit. It was financially supported by INIA projects RTA-2007 00033-C02-01 and RTA2011 00056-C02-00. The authors thank the staff of LIMIA for help with the tank experiments.

\section{REFERENCES}

Adam M.S., Kirkwood G.P. 2001. Estimating tag-shedding rates for skipjack tuna, Katsuwonus pelamis, off the Maldives. Fish. Bull. 99: 193-196.

Arechavala-Lopez P., Uglem I., Izquierdo-Gomez D., et al. 2017. Rapid dispersion of escaped meagre (Argyrosomus regius) from a coastal Mediterranean fish farm. Aquac. Res. 48: 1502-1512. https://doi.org/10.1111/are.12986

Astorga N., Afonso J.M., Zamorano M.J., et al. 2005. Evaluation of visible implant elastomer tags for tagging juvenile gilthead seabream (Sparus auratus L.); effects on growth, mortality, handling time and tag loss. Aquac. Res. 36: 733-738. https://doi.org/10.1111/j.1365-2109.2004.01178.x

Bell J.D., Bartley D.M., Lorenzen K., et al. 2006. Restocking and stock enhancement of coastal fisheries: Potential, problems and progress. Fish. Res. 80: 1-8. https://doi.org/10.1016/j.fishres.2006.03.008

Blankenship H.L., Leber K.M. 1995. A responsible approach to marine stock enhancement. Am. Fish. Soc. Symp. 15: 167-175.

Booth A.J., Weyl O.L.F. 2008. Retention of T-bar anchor and dart tags by a wild population of African sharptooth catfish, Clarias gariepinus. Fish. Res. 92: 333-339. https://doi.org/10.1016/j.fishres.2008.02.002

Brennan N.P., Leber K.M., Blankenship H.L., et al. 2005. An evaluation of coded wire and elastomer tag performance in juvenile common snook under field and laboratory conditions. North Am. J. Fish. Manage. 25: 437-445. https://doi.org/10.1577/M04-003.1

Buzby K., Deegan L. 1999. Retention of anchor and passive integrated transponder tags by arctic grayling. North Am. J. Fish. Manage. 19: 1147-1150.

https://doi.org/10.1577/1548-8675(1999)019<1147:ROAAPI> $2.0 . \mathrm{CO} \cdot 2$

Catalano M.J., Chipps S.R., Bouchard M.A., et al. 2001. Evaluation of injectable fluorescent tags for marking centrarchid fishes: retention rate and effects on vulnerability to predation. North Am. J. Fish. Manage. 21: 911-917. https://doi.org/10.1577/1548-8675(2001)021<0911:EOIFTF>2 $0 . \mathrm{CO} ; 2$

Crawley M.J. 2007. The R Book. John Wiley \& Sons Ltd, USA, $950 \mathrm{pp}$. https://doi.org/10.1002/9780470515075

Chick R.C. 2010. Batch-tagging blacklip abalone (Haliotis rubra) for identification of hatchery-reared individuals on natural coastal reefs in New South Wales, Australia. J. Shellfish Res.
29: 209-215. https://doi.org/10.2983/035.029.0117

Dunning D.J., Ross Q.E., Waldman J.R., et al. 1987. Tag retention by, and tagging mortality of, Hudson River striped bass. North Am. J. Fish. Manage. 7: 535-538.

https://doi.org/10.1577/1548-8659(1987)7<535:TRBATM> 2.0.CO;2

Ebener M.P., Copes F.A. 1982. Loss of Floy anchor tags from lake whitefish. North Am. J. Fish. Manage. 2: 90-93. https://doi.org/10.1577/1548-8659(1982)2<90:LOFATF> 2.0.CO;2

Gil M.M., Palmer M., Grau A., et al. 2014a. Adapting to the wild: the case of aquaculture-produced and released meagres Argyrosomus regius. J. Fish Biol. 84: 10-30. https://doi.org/10.1111/jfb.12241

Gil M.M., Palmer M., Grau A., et al. 2014b. First evidence on the growth of hatchery-reared juvenile meagre Argyrosomus regius released in the Balearic Islands coastal region. Aquaculture 434: 78-87.

https://doi.org/10.1016/j.aquaculture.2014.07.032

Gil M.M., Palmer M., Grau A., et al. 2015. Many vulnerable or a few resilient specimens? Finding the optimal for reintroduction/ restocking programs. PLoS ONE 10: e0138501. https://doi.org/10.1371/journal.pone.0138501

González-Quirós R., del Árbol J., García-Pacheco M.M., et al. 2011. Life-history of the meagre Argyrosomus regius in the Gulf of Cádiz (SW Iberian Peninsula). Fish. Res. 109: 140-149. https://doi.org/10.1016/j.fishres.2011.01.031

Hartman K.J., Janney E.C. 2006. Visual implant elastomer and anchor tag retention in largemouth bass. North Am. J. Fish. Manage. 26: 665-669. https://doi.org/10.1577/M04-166.1

Henderson-Arzapalo A., Rago P., Skjeveland J., et al. 1999. An evaluation of six internal anchor tags for tagging juvenile striped bass. North Am. J. Fish. Manage. 19: 482-493. https://doi.org/10.1577/1548-8675(1999)019<0482:AEOSIA> 2.0.CO;2

Jiménez M.T., Pastor E., Grau A., et al. 2005. Revisión del cultivo de esciénidos en el mundo, con especial atención a la corvina Argyrosomus regius (Asso, 1801). Bol. Inst. Esp. Oceanogr. 21: 169-175.

Josephson D.C., Robinson J.M., Weidel B.C., et al. 2008. Longterm retention and visibility of visible implant elastomer tags in brook trout. North Am. J. Fish. Manage. 28: 1758-1761. https://doi.org/10.1577/M08-019.1

Kerwath S.E., Götz A., Wilke C., et al. 2006. A comparative evaluation of three methods used to tag South African linefish. Afr. J. Mar. Sci. 28: 637-643. https://doi.org/10.2989/18142320609504213

Leber K.M., Blankenship H.L. 2011. How advances in tagging technology improved progress in a new science: marine stock enhancement. Am. Fish. Soc. Symp. 76: 1-12.

Lorenzen K. 2005. Population dynamics and potential of fisheries stock enhancement: practical theory for assessment and policy analysis. Philos. Trans. R. Soc. Lond. B 360: 171-189. https://doi.org/10.1098/rstb.2004.1570

Mayol J., Grau A.M., Riera F., et al. 2000. Llista Vermella dels Peixos de les Balears. Conselleria de Medi Ambient-Conselleria d'Agricultura i Pesca, Spain, 126 pp.

Morales-Nin B., Grau A., Pérez-Mayol S., et al. 2010. Marking of otoliths, age validation and growth of Argyrosomus regius juveniles (Sciaenidae). Fish. Res. 106: 76-80. https://doi.org/10.1016/j.fishres.2010.07.006

Morgan M.J., Walsh S.J. 1993. Evaluation of the retention of external tags by juvenile American plaice (Hippoglossoides platessoides) using an aquarium experiment. Fish. Res. 16: 1-7. https://doi.org/10.1016/0165-7836(93)90105-G

Muoneke M.I. 1992. Loss of Floy anchor tags from white bass. North Am. J. Fish. Manage. 12: 819-824. https://doi.org/10.1577/1548-8675(1992)012<0819:LOFATF> 2.3. $\mathrm{CO} ; 2$

Otterå H., Kristiansen T.S., Svåsand T. 1998. Evaluation of anchor tags used in sea-ranching experiments with atlantic cod (Gadus morhua L.). Fish. Res. 35: 237-246. https://doi.org/10.1016/S0165-7836(97)00055-6

Pastor E., Rodríguez-Rúa A., Grau A., et al. 2013. Hormonal spawning induction and larval rearing of meagre, Argyrosomus regius (Pisces: Sciaenidae). Boll. Soc. Hist. Nat. Balears 56: 111-127.

Phelps R.P., Rodriguez D. 2011. Effects of tag type on red snapper Lutjanus campechanus tag retention, growth and survival under 
hatchery conditions. J. Appl. Ichthyol. 27: 1169-1172. https://doi.org/10.1111/j.1439-0426.2011.01787.x

Quéméner L. 2002. Le maigre commun (Argyrosomus regius). Biologie, peche, marche et potentiel aquacole. Editions IFREMER, France.

Quéro J.C., Vayne J.J. 1987. The meagre, Argyrosomus regius (Asso, 1801) (Pisces, Perciformes, Sciaenidae) from the Bay of Biscay and from more septentrional waters. Rev. Trav. lnst. Pêches Marit. 49: 35-66.

Rude N.P., Whitledge G.W., Phelps Q.E., et al. 2011. Long-term PIT and T-bar anchor tag retention rates in adult muskellunge. North Am. J. Fish. Manage. 31: 515-519. https://doi.org/10.1080/02755947.2011.593962

Sánchez-Lamadrid A. 2001. Effectiveness of four methods for tagging juveniles of farm-reared gilthead sea bream, Sparus aurata, L. Fish. Manage. Ecol. 8: 271-278. https://doi.org/10.1046/j.1365-2400.2001.00249.x

Sato T., Nanami A., Takebe T., et al. 2016. Retention rates of plastic-infusion-process passive integrated transponder tags and external tags in the white-streaked grouper Epinephelus ongus. North Am. J. Fish. Manage. 36: 116-121 https://doi.org/10.1080/02755947.2015.1114536

Schnute J., Fournier D. 1980. A new approach to length-frequency analysis: growth structure. Can. J. Fish. Aquat. Sci. 37: $1337-1351$ https://doi.org/10.1139/f80-172

Venerus L.A., Irigoyen A.J., Parma A.M. 2013. Assessment of biases in the estimation of tag shedding rates through a markresight experiment. Fish. Res. 140: 133-148.

https://doi.org/10.1016/j. fishres. 2012.12.015

Vogelbein W.K., Overstreet R.M. 1987. Histopathology of the internal anchor tag in spot and spotted seatrout. Trans. Am. Fish. Soc. 116: $745-756$

https://doi.org/10.1577/1548-8659(1987)116<745:HOTIAT>2 .0. $\mathrm{CO} ; 2$

Waldman J.R., Dunning D.J., Mattson M.T. 1991. Management briefs: Long-term retention of anchor tags and internal anchor tags by striped bass. North Am. J. Fish. Manage. 11: 232-234. https://doi.org/10.1577/1548-8675(1991)011<0232:MBLTRO $>2.3 . \mathrm{CO} ; 2$

Wallin J.E., Ransier J.M., Fox S., et al. 1997. Short-term retention of coded wire and internal anchor tags in juvenile common snook, Centropomus undecimalis. Fish. Bull. 95: 873-878.

Wetherall J.A. 1982. Analysis of double tagging experiments. Fish. Bull. 80: 687-701.

Ye Y., Loneragan N., Die D., et al. 2005. Bioeconomic modelling and risk assessment of tiger prawn (Penaeus esculentus) stock enhancement in Exmouth Gulf, Australia. Fish. Res. 73: 231-249.

https://doi.org/10.1016/j.fishres.2004.12.004 